\title{
Distribution Characteristics and Risk Assessment of Mercury in Sediments From Taihu Lake
}

\author{
Hailei Su, Di Shi, Jiwei Yang, Yanru Tao, Fuhong Sun * and Yuan Wei* \\ State Key Laboratory of Environmental Criteria and Risk Assessment, Chinese Research Academy of Environmental Sciences, \\ Beijing, China
}

OPEN ACCESS

Edited by:

Shuwen Yan,

Fudan University, China

Reviewed by:

Yunsong $\mathrm{Mu}$,

Renmin University of China, China

$\mathrm{Jia} \mathrm{He}$

Beijing Normal University, China

Ning Qin,

University of Science and Technology

Beijing, China

*Correspondence:

Fuhong Sun

sunfhiae@126.com

Yuan Wei

weiyuanshiwo@126.com

Specialty section:

This article was submitted to

Toxicology, Pollution and the

Environment,

a section of the journal

Frontiers in Environmental Science

Received: 15 April 2021 Accepted: 08 June 2021

Published: 29 June 2021

Citation:

Su H, Shi D, Yang J, Tao Y, Sun F and Wei Y (2021) Distribution

Characteristics and Risk Assessment of Mercury in Sediments From

Taihu Lake.

Front. Environ. Sci. 9:695470 doi: 10.3389/fenvs.2021.695470
Persistent pollutants are easily accumulated in sediments, which can cause toxicity to benthos and secondary pollution to water. Mercury $(\mathrm{Hg})$, as one kind of bioaccumulative and persistent pollutant, could cause great harm to water ecology and health, and has been widely concerned. The distribution characteristics and ecological risk of $\mathrm{Hg}$ in sediments from Taihu Lake were studied. In addition, the sediment quality criterion (SQC) of Hg was derived using tissue-based toxicity data combined with the phaseequilibrium partitioning (EqP) approach, and the ecological risk level of $\mathrm{Hg}$ in Taihu Lake sediment was evaluated. The results showed that $\mathrm{Hg}$ was detected in all the 30 sediment samples, and the concentrations of $\mathrm{Hg}$ ranged from $9.7 \mathrm{ng} / \mathrm{g}$ to $237.0 \mathrm{ng} / \mathrm{g}$, with an average of $76.3 \mathrm{ng} / \mathrm{g}$. The SQC of Hg was calculated to be $108.9 \mathrm{ng} / \mathrm{g}$, and the ecological risk of $\mathrm{Hg}$ in the sediments of Taihu Lake is in the middle level, indicating that $\mathrm{Hg}$ pollution needs to be paid more attention. The results provide support for environmental management and risk assessment of $\mathrm{Hg}$.

Keywords: mercury, sediment quality criteria, risk assessment, Taihu Lake, bioaccumulation

\section{INTRODUCTION}

Sediment is not only the habitat of benthos but also an important part of the aquatic ecosystem as it is the "sink" and "source" of pollutants. Therefore, it is very important to protect them from pollution to maintain a good aquatic ecological environment (Zhu et al., 2009a; Shang et al., 2012). The sediment quality criterion (SQC) is a critical level to protect aquatic life associated with sediment from pollutants. Besides, the SQC can also be used to evaluate the impact of pollutants combined with sediments and provide a basis for scientific management of sediments (Gaudet et al., 1995; MacDonald et al., 2000). The research on SQC abroad began in the 1980s, and several methods for establishing the SQC have been put forward. Among them, the phaseequilibrium partitioning $(\mathrm{EqP})$ approach and biological effect database method are widely used (Zhu et al., 2009a; MacDonald et al., 2000; Chen et al., 2006a). The EqP approach was proposed by the U.S. Environmental Protection Agency in 1985 (USEPA, 2005) and is the first choice to establish a numerical SQC (Burton, 2002). Many countries and regions have also carried out studies on the SQC (Van et al., 1991; Webster and rodhway, 1994; Smith et al., 1996; MacDonald et al., 2003; Simpson et al., 2011). As environmental criteria have regional property, it is necessary for China to embark on development of its own national environmental criteria ( $\mathrm{Wu}$ et al., 2010). The research on the SQC in China started later and due to the lack of biological toxicological data and field biological monitoring data, the EqP approach was adopted in several studies in China (Liu et al., 1999; Chen et al., 2006b; Zhu et al., 2009b). The water quality 


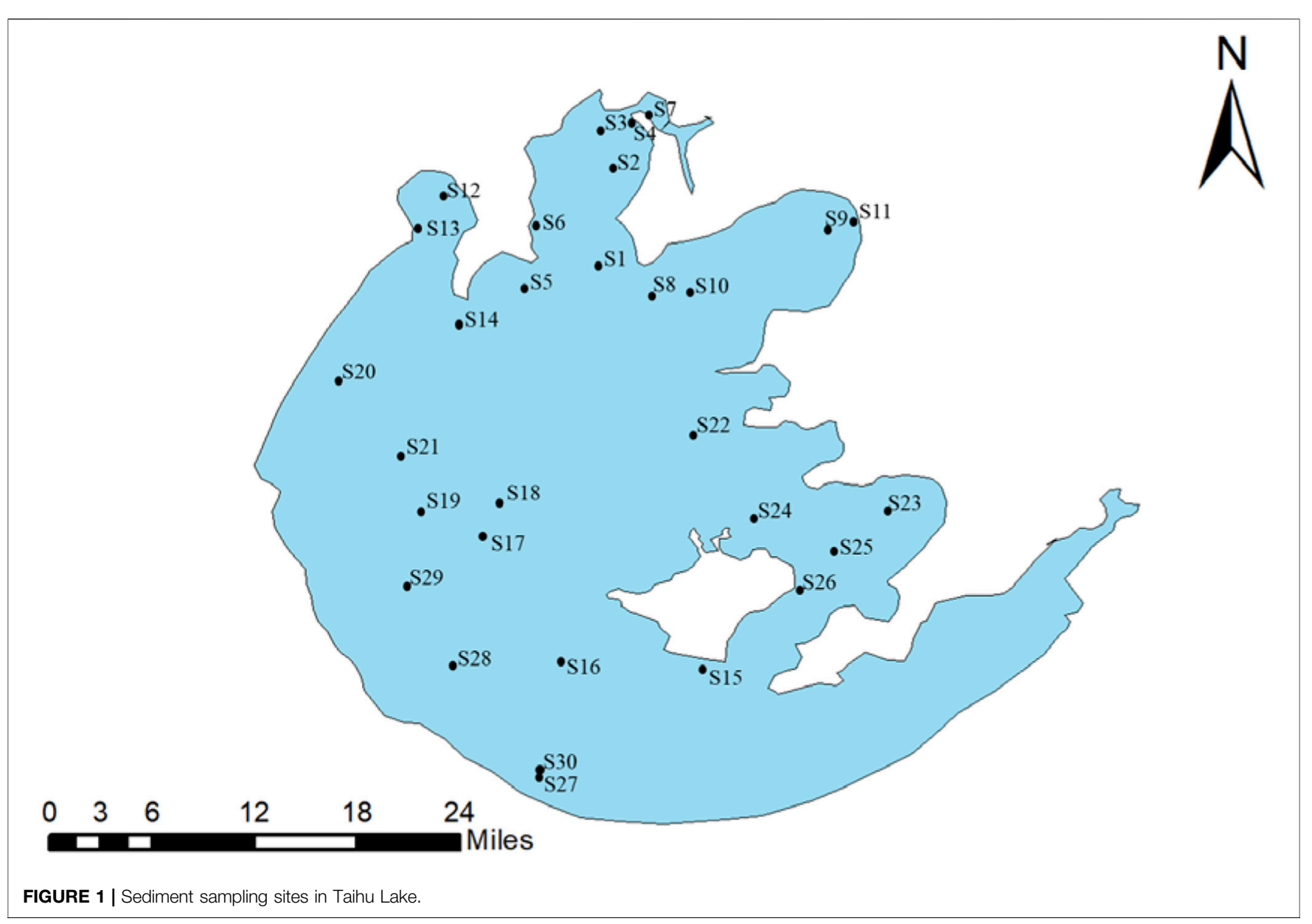

criterion (WQC) was determined based on the species sensitivity distribution (SSD) method, and the SQC was derived using the EqP approach (Jiang et al., 2020). And then the ecological risk level of heavy metals in the sediments was evaluated ( $\mathrm{Li}$ et al., 2020).

Mercury $(\mathrm{Hg})$ is a toxic element that poses harmful effects on human and ecosystem health even at extremely low concentrations. After entering the environment, $\mathrm{Hg}$ could be enriched in water, sediments, and aquatic organisms (such as benthos and fish), and poison people and other animals through the food chain (Grandjean, 2007). It is necessary to study the SQC and ecological risk assessment of mercury for the protection of the aquatic ecosystem. Several studies have been conducted on the risk assessment of mercury in sediment by the geo-accumulation index (Igeo) (Niu et al., 2019; Wen et al., 2020), and $\mathrm{Hg}$ has been identified to have high ecological risk in some sediment (Zhuang and Gao, 2015).

Taihu Lake, located in the south of Jiangsu Province and the east of Yangtze River Delta, is the second largest freshwater lake in China. In recent years, due to the development of Wuxi, Changzhou, Suzhou, and other industrial cities around the North Taihu Lake, its surrounding environment has deteriorated rapidly, which has brought serious impact on the production and life of the local people. Several studies have been carried out on concentrations and ecological risk assessment of $\mathrm{Hg}$ in sediments from Taihu Lake (Xu and Zhang, 2013; Chen et al., 2013; Hu et al., 2014). However, the SQC for mercury in Taihu Lake has not been derived. In addition, due to the bioaccumulation of mercury, the WQC derived from water-based toxicity data may cause the problem of under protection of aquatic organisms (Su et al., 2020). The water-based toxicity data are expressed as the concentrations of chemicals in water above which harmful effects would be caused to the aquatic species, while the tissue-based toxicity data are expressed as the concentrations of chemicals in tissue of aquatic life above which harmful effects would be caused to the aquatic species. So, there is a recognized need to develop the WQC using tissue-based toxicity data for protection of aquatic ecosystems (Gaudet et al., 1995; Conder et al., 2015). In this study, the distribution characteristics of $\mathrm{Hg}$ in sediment from Taihu Lake were studied and analyzed. Besides, the SQC of $\mathrm{Hg}$ was derived by the EqP method using tissue-based toxicity data, and the ecological risk of $\mathrm{Hg}$ was evaluated. The purpose of this study was to provide support for SQC derivation and risk management of mercury in sediments. 


\section{MATERIALS AND METHODS}

\section{Sample Collection and Treatment}

A total of 30 surficial sediment samples were collected using a grab sampler in September 2019 (see Figure 1). The surface sediment $(0-20 \mathrm{~cm})$ was collected, and the undisturbed $0-2 \mathrm{~cm}$ surface sediment samples were taken with plastic spoon and sealed with polyethylene self-sealing bags. Within $24 \mathrm{~h}$ of collection, all sample bags were transported to the laboratory in an ice-cooled container, and stored in the refrigerator $\left(4^{\circ} \mathrm{C}\right)$ until analysis.

\section{Sample Analysis and Determination}

In the laboratory, after being freeze-dried, ground, and sieved to $<100$ mesh-sized particles, the lake sediment samples were subjected to acid digestion for $\mathrm{Hg}$ analysis, and $0.2 \mathrm{~g}$ of dry weight (dw) sample (accurate to $0.0002 \mathrm{~g}$ ) was placed inside a 50$\mathrm{ml}$ glass tube covered with a glass ball, and $5 \mathrm{ml}$ of doubledeionized water and $5 \mathrm{ml}$ fresh aqua regia $\left(\mathrm{HCl}+\mathrm{HNO}_{3}, \mathrm{~V} / \mathrm{V}, 3\right.$ : 1) were added, and digested in boiling water for $2 \mathrm{~h}$. Then the sample was diluted to $50 \mathrm{ml}$ with double-deionized water after cooling, and the supernatant was taken to be tested using atomic fluorescence spectrometry (HG-AFS, Millennium Merlin, PSA 10.063., PS Analytical Ltd., United Kingdom). The blank solution was prepared with the same reagent and procedure. At least two blank solutions shall be prepared for each batch of samples.

\section{Derivation of SQC for $\mathbf{H g}$}

The SQC of mercury in this study was derived by the EqP method using Eq. 1 (Huo et al., 2013):

$$
\mathrm{SQC}=\mathrm{K}_{\mathrm{P}} \cdot \mathrm{WQC},
$$

where SQC is the sediment quality criterion $(\mathrm{mg} / \mathrm{kg}), \mathrm{WQC}$ is the water quality criterion $(\mathrm{mg} / \mathrm{L})$, and $\mathrm{K}_{\mathrm{P}}$ is the partition coefficient of heavy metals between solid phase and interstitial water $(\mathrm{L} / \mathrm{kg})$.

As bioaccumulative chemicals could bioaccumulate through the food chain, even very low concentrations in water would result in very high concentrations in organisms. Accordingly, traditional WQC based on toxicity data expressed as concentrations in water might not provide full protection for aquatic life from bioaccumulative pollutants (USEPA, 2016). It is believed that the concentrations based on tissue could reflect the bioavailability of bioaccumulative pollutants, so the tissue-based criteria derived from toxicity data expressed as concentrations in tissue could provide scientific protection for aquatic organisms for such chemicals (McElroy et al., 2011; Sappington et al., 2011). The WQC here was calculated from tissue-based criterion (TBC) and bioaccumulation factor (BAF) using Eq. 2 (Su et al., 2015):

$$
\mathrm{WQC}=\mathrm{TBC} / \mathrm{BAF},
$$

where TBC is the tissue-based criterion derived by the species sensitive distribution (SSD) method using tissue-based toxicity data of $\mathrm{Hg}$ on aquatic species $(\mathrm{mg} / \mathrm{kg})$ and $\mathrm{BAF}$ is the bioaccumulation factor of $\mathrm{Hg}(\mathrm{L} / \mathrm{kg})$.

Toxicological data collection: the tissue-based toxicity data for $\mathrm{Hg}$ on aquatic species were collected from the U.S. Environmental
Residue-Effects Database (ERED) (https://ered.el.erdc.dren.mil/) and related publications. The screening of toxicity data was conducted following the published literature (Su et al., 2020). The no-observed effect concentrations (NOECs) were selected to fit the SSD. When the NOEC was not available, the NOEC was estimated using the lowest observed effect concentration (LOEC) value by Eq. 3 (Balk et al., 1995).

$$
\mathrm{NOEC}=\mathrm{LOEC} / 2 .
$$

The China-WQC software was employed to fit the distribution and the calculated $\mathrm{HC}_{5}$ (hazard concentration affecting $5 \%$ of species) is the TBC.

\section{Risk Assessment of $\mathrm{Hg}$ in Sediment}

Till now, several methods have been developed to evaluate the ecological risk assessment of heavy metals in sediment, including geo-accumulation indexes (Hu et al., 2014; Niu et al., 2019), risk assessment code (Wang et al., 2017), and risk quotient (Du et al., 2015). Among them, the risk quotient (RQ) is the most feasible method for the risk characterization of pollutants in environment and has been used to evaluate the risk level of $\mathrm{Hg}$ in sediment ( $\mathrm{Du}$ et al., 2015). Based on the $\mathrm{Hg}$ concentrations in Taihu Lake sediment and the SQC of $\mathrm{Hg}$ derived in this study, the RQ method was used to evaluate the ecological risk of mercury. If $R Q \geq 1$, the risk posed by $\mathrm{Hg}$ is high; if $0.1<\mathrm{RQ}<1.0$, the ecological risk is moderate; if $\mathrm{RQ} \leq 0.1$, the ecological risk is low. The RQ was calculated by Eq. 4 as follows:

$$
\mathrm{RQ}=\mathrm{MEC} / \mathrm{SQC},
$$

where MEC (ng/g) is the measured environmental concentration.

\section{Quality Assurance and Quality Control}

In the $\mathrm{Hg}$ analytical process, all the sediment samples collected from Taihu Lake and blanks were analyzed in duplicate for quality assurance and quality control. Only relative standard deviation (RSD) values below 10\% were accepted, while samples outside this range were reanalyzed. Methods used to determine sample indexes were obtained from the "Ministry of Ecology and Environment of the People's Republic of China Protection" standard methods. The variance of standard curve adopted in this study ranged from 0.92 to 0.95 . Besides, the limit of detection (LOD) in sediments was $0.01 \mathrm{mg} / \mathrm{L}$ for $\mathrm{Hg}$. The recovery of $\mathrm{Hg}$ was $94.5-102.6 \%$ in sediment. The statistical analysis was processed using Origin 8.0, and the SSD curve of $\mathrm{Hg}$ for aquatic species was fitted by use of China-WQC software.

\section{RESULTS AND DISCUSSION}

\section{Distribution Characteristics of $\mathrm{Hg}$ Concentrations in Taihu Lake Sediment}

Statistical analysis results of $\mathrm{Hg}$ concentrations in sediment from Taihu Lake are presented in Table 1. The original $\mathrm{Hg}$ concentrations resulted in a positively skewed distribution and a normally distribution following a logarithmic transformation (see Figure 2). The concentrations of $\mathrm{Hg}$ ranged from $9.7 \mathrm{ng} / \mathrm{g}$ to 
TABLE 1 | Hg concentrations in sediments from several regions in China (ng/g).

\begin{tabular}{|c|c|c|c|c|c|}
\hline Time & Location & Min & Max & Mean & References \\
\hline 2012 & Miyu Reservoir & 50.0 & 210.0 & 90.0 & Qiao et al. (2013) \\
\hline 2010 & Aha Reservoir & 160.0 & 250.0 & 210.0 & Bai et al, (2011) \\
\hline 2009 & Yellow River Estuary wetland & 10.0 & 102.0 & 55.0 & Liu et al, (2012) \\
\hline 2013 & Confluence area of Lake Chaohu & 210.0 & 290.0 & 269.0 & Liu et al, (2014) \\
\hline 2010 & Rivers in Shanghai & 140.0 & $1,340.0$ & 610.0 & Jia et al, (2013) \\
\hline 2005 & Songhua River & 9.8 & $1,273.3$ & 370.3 & Lin et al, (2007) \\
\hline 2005-2009 & Changjiang Estuary and its adjacent areas & 26.0 & 194.0 & 110.0 & Li et al, (2012) \\
\hline 2019 & Yangcheng Lake & 50.0 & 260.0 & 90.0 & Guo et al, (2019) \\
\hline 2016 & Main stream of Yangtze River & 11.3 & 567.6 & 106.9 & Zhai et al, (2017) \\
\hline 2013 & Circum-Chaohu Basin & 10.0 & $1,100.0$ & 200.0 & Kong et al, (2015) \\
\hline 2007 & Lake Taihu & 30.0 & 330.0 & 160.0 & Yin et al, (2011) \\
\hline 2010 & Lake Taihu & 23.0 & 168.0 & 55.0 & Chen et al, (2013) \\
\hline 2019 & Lake Taihu & 9.7 & 237.0 & 76.3 & This study \\
\hline
\end{tabular}
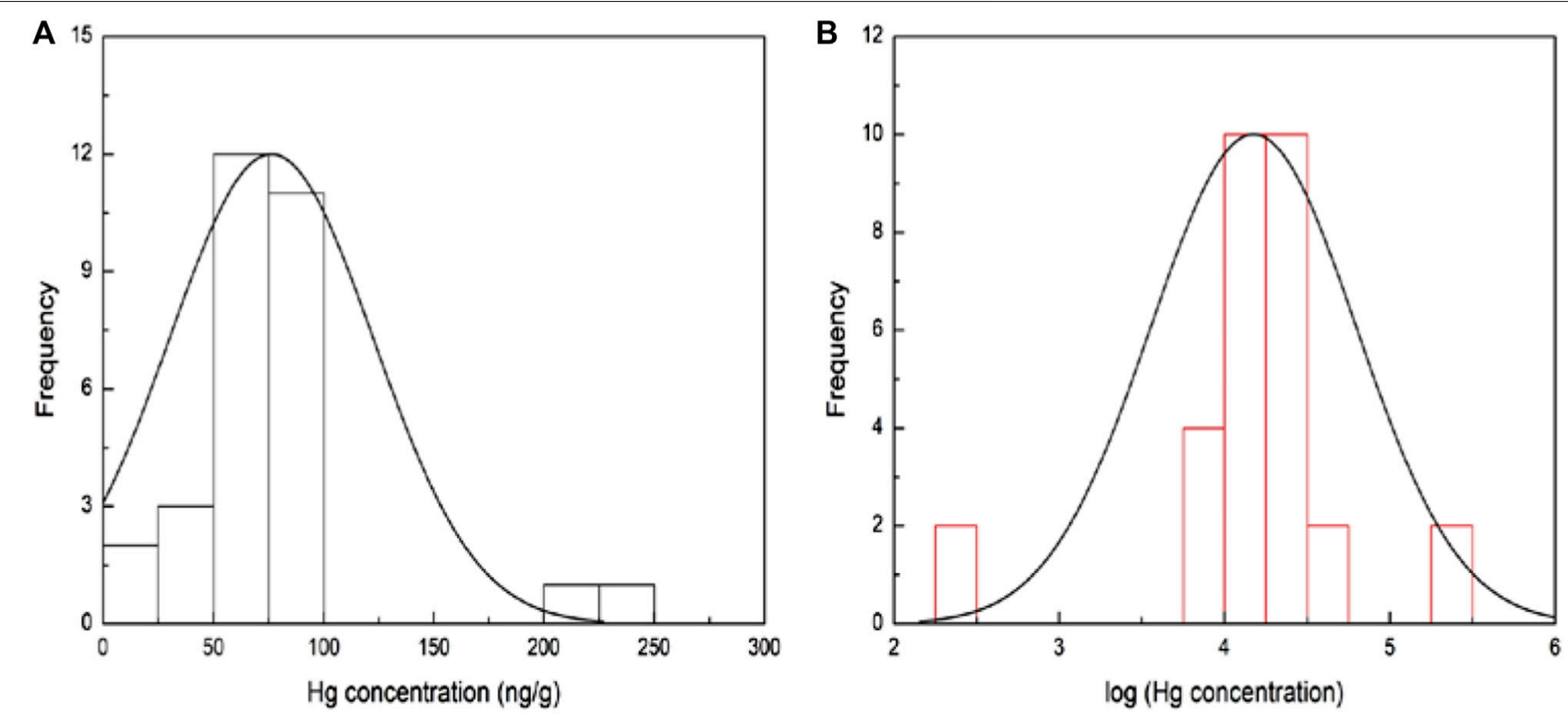

FIGURE 2 | Histogram of frequency of $\mathrm{Hg}$ concentrations in sediments of Taihu Lake.

$237.0 \mathrm{ng} / \mathrm{g}$, with an average of $76.3 \mathrm{ng} / \mathrm{g}$. The industrial development of cities around Taihu Lake is different, resulting in different levels of mercury pollution in sediments of different regions of Taihu Lake. The main sources of mercury pollution in Taihu Lake sediments are chemical industry, paint industry, electronics industry, plastics industry, pharmaceutical industry, and mercury pesticide industry.

The Hg concentrations in sediment from different regions in China were reviewed, and the results are summarized in Table 1. It can be seen from Table 1 that the concentrations of $\mathrm{Hg}$ in freshwater sediment in China ranges from less than $10.0 \mathrm{ng} / \mathrm{g}$ to more than $1,000.0 \mathrm{ng} / \mathrm{g}$, and the average range is $55.0-610.0 \mathrm{ng} / \mathrm{g}$. For the Yellow River estuary wetland, Miyu Reservoir, and Changjiang Estuary, the $\mathrm{Hg}$ concentrations in the sediment are relatively lower, with maximum concentrations about $200.0 \mathrm{ng} / \mathrm{g}$, while the $\mathrm{Hg}$ concentrations in sediments from the Chaohu Basin,
Songhua River, and rivers in Shanghai are the most serious, with maximum concentrations over $1,000.0 \mathrm{ng} / \mathrm{g}$. The concentrations of $\mathrm{Hg}$ in the sediment of Taihu Lake are lower than those in most lakes and reservoirs. Compared with previous studies, the maximum $\mathrm{Hg}$ concentrations in sediments of Taihu Lake decreased from $330.0 \mathrm{ng} / \mathrm{g}$ to about $200.0 \mathrm{ng} / \mathrm{g}$, and the average concentrations decreased from $160.0 \mathrm{ng} / \mathrm{g}$ to about $70.0 \mathrm{ng} / \mathrm{g}$, indicating that $\mathrm{Hg}$ pollution has been effectively controlled. However, the maximum and average concentrations of $\mathrm{Hg}$ in this study are higher than those in the study conducted in 2010, indicating that the $\mathrm{Hg}$ pollution in Taihu sediment still needs attention.

$\mathrm{Xu}$ and Zhang, 2013 studied the distribution characteristics and pollution of $\mathrm{Hg}$ in surface sediments of Lake Wetlands in Taihu Lake Basin, and results showed that the sediment from Yixing, Suzhou, Wuxi, and Huzhou was moderately polluted. Chen et al. (2013) studied the distribution of $\mathrm{Hg}$ in surface 
sediments from different regions of Taihu Lake, and the results showed that the $\mathrm{Hg}$ concentrations ranged from 23.0 to $168.0 \mathrm{ng} /$ $\mathrm{g}$, with an average concentration of $55.0 \mathrm{ng} / \mathrm{g}$. The ecological risk assessment of $\mathrm{Hg}$ in the sediments of North Taihu Lake was evaluated by land accumulation index method, and the results showed that the sediment of North Taihu Lake was in a moderate pollution level (Hu et al., 2014).

\section{Derivation of the SQC of $\mathrm{Hg}$ for Taihu Lake}

As mentioned earlier, the tissue-based toxicity data of $\mathrm{Hg}$ on aquatic species were obtained from the ERED database. The obtained data that could be used to fit the SSD are shown in Table 2 after being screened and summarized.

Finally, the obtained NOEC was used to fit the SSD of $\mathrm{Hg}$ on aquatic species by China-WQC software, as shown in Figure 2. For the experimental data with only the LOEC obtained, the NOEC was estimated by Eq. 3. The TBC $\left(\mathrm{HC}_{5}\right)$ of $\mathrm{Hg}$ was calculated to be $0.062 \mathrm{mg} / \mathrm{kg}\left(R^{2}=0.97\right)$ (Figure 3). Compared with the EQS-biota of $0.02 \mathrm{mg} / \mathrm{kg}$ issued by the European Union (ECB, 2013), the TBC of $\mathrm{Hg}$ derived in this study is a little higher but in the same order of magnitude.

In order to obtain a scientific WQC of $\mathrm{Hg}$ for protection of aquatic species in Taihu Lake, the WQC of $\mathrm{Hg}$ was derived by using the site-specific BAF of $\mathrm{Hg}$ in Taihu Lake in Eq. 2. According to the reported literature ( $\mathrm{Hu}$ et al., 2014), the average concentrations of $\mathrm{Hg}$ in water and aquatic organisms of Taihu Lake are $26.7 \mathrm{ng} / \mathrm{L}$ and $48.2 \mathrm{ng} / \mathrm{g}$, respectively. The calculated BAF of aquatic organisms for $\mathrm{Hg}$ in Taihu Lake is $1800 \mathrm{~L} / \mathrm{kg}$. Then using Eq. 2, the WQC of Hg in Taihu Lake was calculated to be $34.4 \mathrm{ng} / \mathrm{L}$, which is close to the MACEQC of $\mathrm{Hg}$ issued by the European Union (ECB, 2013). However, this WQC is much smaller than the WQC of $467.0 \mathrm{ng} / \mathrm{L}$ for aquatic life protection derived using waterbased toxicity data of $\mathrm{Hg}$ (Zhang et al., 2012), indicating that the WQC calculated by tissue-based toxicity data could provide better protection for the aquatic ecosystem for bioaccumulative pollutants as it considered the bioaccumulation capacity.

It was reported that the partitioning coefficients $(\log \mathrm{Kp})$ of $\mathrm{Hg}$ between particulate matter and water in the Yangtze River are 2.5-4.2, with an average of 3.5 (Huo and Chen, 1997). Based on the average $\mathrm{Kp}(3,162.3 \mathrm{~L} / \mathrm{kg})$ and the WQC of $\mathrm{Hg}$ derived in this study, the SQC of $\mathrm{Hg}$ in Taihu Lake was calculated to be $108.9 \mathrm{ng} / \mathrm{g}$ using Eq. 1. However, the SQC of Hg was calculated to be $1,476.8 \mathrm{ng} / \mathrm{g}$ using the WQC of $\mathrm{Hg}$ derived using waterbased toxicity data (Zhang et al., 2012), which is more than

TABLE 2 | Toxic data of $\mathrm{Hg}$ on aquatic species-based tissue.

\begin{tabular}{|c|c|c|c|c|}
\hline Scientific name & Test species group & Toxic effect & Endpoint & Concentrations $(\mathrm{mg} / \mathrm{kg})$ \\
\hline Perca flavescens & Fishes & Growth & NOEC & 0.135 \\
\hline Salmo salar & Fishes & Growth & NOEC & 0.03 \\
\hline Ameiurus melas & Fishes & Biochemistry & NOEC & 0.61 \\
\hline Oncorhynchus keta & Fishes & Mortality & NOEC & 0.8 \\
\hline Anabas testudineus & Fishes & Mortality & NOEC & 2.8 \\
\hline Anguilla anguilla & Fishes & Mortality & LOEC & 13.4 \\
\hline Pimephales promelas & Fishes & Growth & NOEC & 10.69 \\
\hline Liza aurata & Fishes & Cellular & NOEC & 0.1 \\
\hline Thymallus thymallus & Fishes & Growth & NOEC & 3.8 \\
\hline Carassius auratus & Fishes & Mortality & NOEC & 6.2 \\
\hline Poecilia reticulata & Fishes & Mortality & NOEC & 0.2 \\
\hline Oryzias latipes & Fishes & Reproduction & NOEC & 16 \\
\hline Micropterus salmoides & Fishes & Reproduction & NOEC & 1.23 \\
\hline Brycon amazonicus & Fishes & Biochemistry & LOEC & 0.63 \\
\hline Xiphias gladius & Fishes & Biochemistry & NOEC & 4.4 \\
\hline Sander vitreus & Fishes & Growth & NOEC & 0.25 \\
\hline Pseudopleuronectes americanus & Fishes & Biochemistry & LOEC & 2 \\
\hline Danio rerio & Fishes & Mortality & NOEC & 6.84 \\
\hline Boleophthalmus dussumieri & Fishes & Cellular & LOEC & 0.59 \\
\hline Oncorhynchus mykiss & Fishes & Mortality & NOEC & 4.8 \\
\hline Rangia cuneata & Molluscs & Mortality & LOEC & 73.1 \\
\hline Mytilus edulis & Molluscs & Mortality & NOEC & 1.12 \\
\hline Elliptio complanata & Molluscs & Mortality & NOEC & 3.4 \\
\hline Pyganodon grandis & Molluscs & Growth & NOEC & 0.686 \\
\hline Hexagenia sp & Aquatic insects & Growth & LOEC & 0.131 \\
\hline Chimarra sp & Aquatic insects & Biochemistry & LOEC & 0.166 \\
\hline Maccaffertium modestrum & Aquatic insects & Growth & NOEC & 2.7 \\
\hline Chironomus riparius & Aquatic insects & Mortality & NOEC & 40 \\
\hline Daphnia magna & Crustaceans & Reproduction & NOEC & 0.859 \\
\hline Acartia tonsa & Crustaceans & Reproduction & NOEC & 0.048 \\
\hline Uca pugnax & Crustaceans & Development & LOEC & 12.3 \\
\hline Palaemonetes pugio & Crustaceans & Mortality & NOEC & 1.64 \\
\hline Hyalella azteca & Crustaceans & Survival & NOEC & 11 \\
\hline Viviparus georgianus & Snails & Mortality & NOEC & 6 \\
\hline Crepidula fornicata & Snails & Reproduction & NOEC & 8 \\
\hline
\end{tabular}




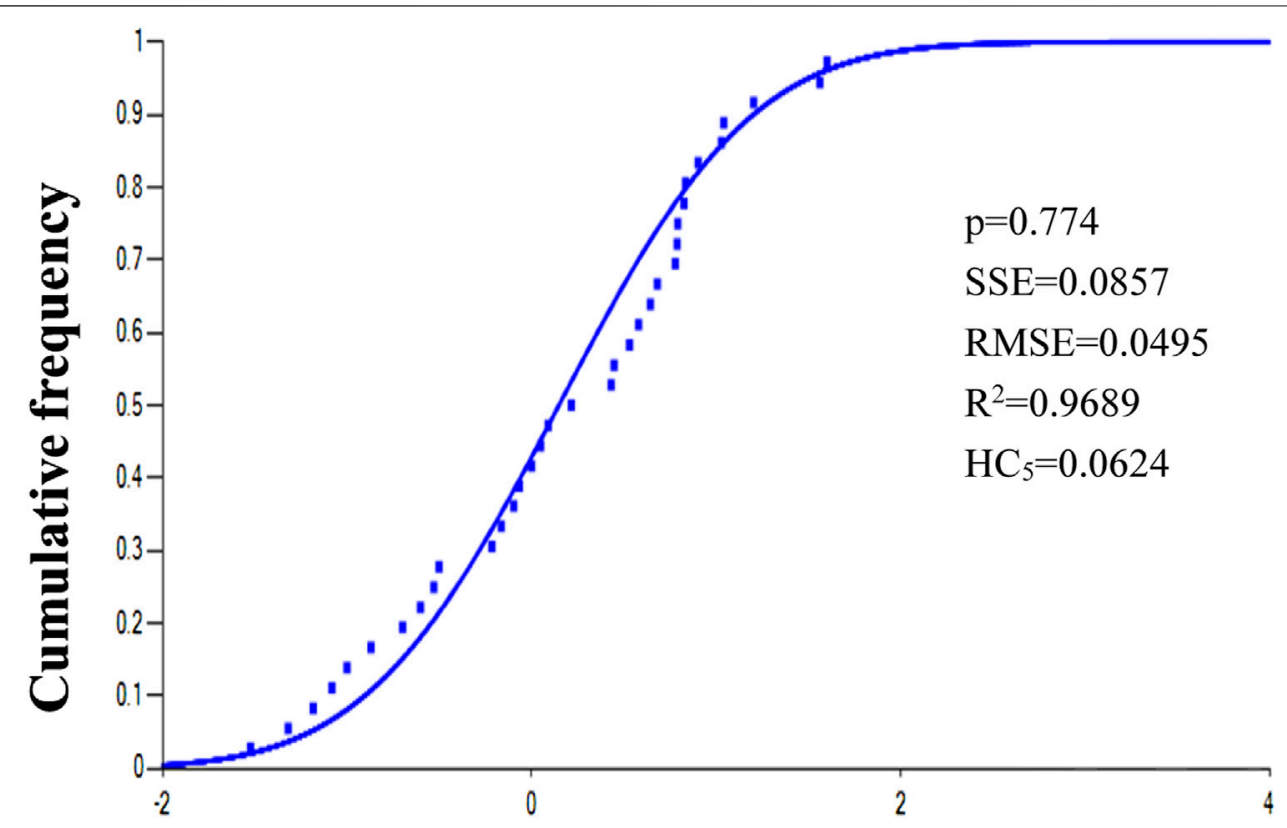

FIGURE 3 | SSD curve of $\mathrm{Hg}$ for aquatic species $\left(\mathrm{HC}_{5}=0.062 \mathrm{mg} / \mathrm{kg}, R^{2}=0.97\right)$.

TABLE 3 | Risk quotients (RQs) of $\mathrm{Hg}$ at the 30 sampling points of Taihu Lake.

\begin{tabular}{lccccc} 
Sampling site & RQ & Sampling site & RQ & Sampling site & RQ \\
\hline S1 & 0.84 & $\mathrm{~S} 11$ & 0.70 & $\mathrm{~S} 21$ & 0.49 \\
S2 & 0.82 & $\mathrm{~S} 12$ & 2.04 & $\mathrm{~S} 22$ & 0.44 \\
S3 & 0.81 & $\mathrm{~S} 13$ & 2.18 & $\mathrm{~S} 23$ & 0.69 \\
S4 & 0.73 & $\mathrm{~S} 14$ & 0.85 & $\mathrm{~S} 24$ & 0.43 \\
S5 & 0.78 & $\mathrm{~S} 15$ & 0.58 & $\mathrm{~S} 25$ & 0.55 \\
S6 & 0.76 & $\mathrm{~S} 16$ & 0.10 & $\mathrm{~S} 26$ & 0.67 \\
S7 & 0.77 & $\mathrm{~S} 17$ & 0.09 & $\mathrm{~S} 27$ & 0.59 \\
S8 & 0.55 & $\mathrm{~S} 18$ & 0.54 & $\mathrm{~S} 28$ & 0.51 \\
S9 & 0.73 & $\mathrm{~S} 19$ & 0.54 & $\mathrm{~S} 29$ & 0.56 \\
S10 & 0.44 & $\mathrm{~S} 20$ & 0.63 & $\mathrm{~S} 30$ & 0.57 \\
\hline
\end{tabular}

10 times of the SQC derived in this study, indicating that the SQC derived using tissue-based toxicity data might be more scientific and rational for bioaccumulative chemicals. The Canadian Environmental Quality Guidelines for $\mathrm{Hg}$ have been recommended, and the interim freshwater sediment guideline values for the protection of aquatic life were reported to be $140.0 \mathrm{ng} / \mathrm{g}$ (Gaudet et al., 1995). Besides, the SQC of $\mathrm{Hg}$ in the Xiangjiang River has also been derived with a SQC-L of $130.0 \mathrm{ng} / \mathrm{g}$ and a SQC-H of $790.0 \mathrm{ng} / \mathrm{g}$ (Jiang et al., 2013). The SQC of Hg for Taihu Lake derived in this study was a little lower but quite close to the SQC of $\mathrm{Hg}$ in Canada and the Xiangjiang River.

\section{Ecological Risk Assessment of $\mathrm{Hg}$ in Taihu Lake Sediment}

Based on the SQC $(108.9 \mathrm{ng} / \mathrm{g})$ derived in this study for Taihu Lake and the $\mathrm{Hg}$ concentrations in the sediment from 30 sampling sites, the RQs of $\mathrm{Hg}$ in Taihu Lake were calculated using Eq. 4, as shown in Table 3.

It can be seen from Table 3 that among the 30 sediment sampling points in Taihu Lake, the RQ values of two sampling points (S12 and S13) are greater than 1, indicating that the ecological risk of $\mathrm{Hg}$ in Taihu Lake sediments still exists. The RQ values of other two sampling points (S16 and S17) are less than or equal to 0.1 , which means that ecological risk of $\mathrm{Hg}$ in these two sites are low, while the RQs of 26 sampling sites are between 0.1 and 1, indicating that the overall ecological risk levels of $\mathrm{Hg}$ in Taihu Lake sediment are moderate. This is consistent with the ecological risk assessment of $\mathrm{Hg}$ in Taihu Lake sediment using the geo-accumulation index method (Hu et al., 2014).

However, if the SQC $(1,468.0 \mathrm{ng} / \mathrm{g})$ derived from water-based toxicity data was used for ecological risk assessment, there is no ecological risk at 30 sediment sampling points in Taihu Lake, indicating that the WQC or SQC derived from water-based toxicity data might cause under protection problem for bioaccumulative substances such as $\mathrm{Hg}$. For bioaccumulative chemicals, SQC derived from tissue-based toxicity data should be used in the evaluation of the ecological risk and would provide more scientific foundation for the environmental management.

\section{CONCLUSION}

1) The concentrations of $\mathrm{Hg}$ ranged from $9.7 \mathrm{ng} / \mathrm{g}$ to $237.0 \mathrm{ng} / \mathrm{g}$, with an average of $76.3 \mathrm{ng} / \mathrm{g}$. And the SQC of $\mathrm{Hg}$ in Taihu Lake was derived to be $108.9 \mathrm{ng} / \mathrm{g}$.

2) The ecological risk of $\mathrm{Hg}$ in Taihu Lake sediments was evaluated according to the SQC, and the ecological risk 
of $\mathrm{Hg}$ in the sediments of Taihu Lake is in the middle level.

3) For bioaccumulative substances, such as $\mathrm{Hg}$, the use of the WQC and SQC derived from water-based toxicity data may cause under protection problems because bioaccumulation is not fully considered. For such substances, it is recommended to derive the SQC and WQC using tissue-based toxicity data.

\section{DATA AVAILABILITY STATEMENT}

The original contributions presented in the study are included in the article/Supplementary Material; further inquiries can be directed to the corresponding authors.

\section{REFERENCES}

Bai, W.-Y., Feng, X.-B., He, T.-R., Qiu, G.-L., and Yan, H.-Y. (2011). Distribution Patterns of Mercury and Methylmercury in Aha Reservoir Sediment. Chin. J. Ecol. 30, 976-980. (in Chinese).

Balk, F., Okkerman, P. C., and Dogger, J. W. (1995). Guidance Document for Aquatic Effects Assessment. Paris, France: Organization for Economic Cooperation and Development, 22-28.

Burton, G. A. (2002). Sediment Quality Criteria in Use Around the World. The Jpn. Soc. Limnology 3, 65-75.

Chen, C., Zheng, B., Jiang, X., Zhao, Z., Zhan, Y., Yi, F., et al. (2013). Spatial Distribution and Pollution Assessment of Mercury in Sediments of Lake Taihu, China. J. Environ. Sci. 25, 316-325. doi:10.1016/s1001-0742(12) 60033-3

Chen, Y.-Z., Yang, H., Zhang, Z.-K., Qin, M.-Z., and Jin, F. (2006b). Application of Equilibrium Partitioning Approach to the Assessment of Sediment Quality in Dian Chi Lake. Acta Scien. Circum. 26, 1545-1552. (in Chinese).

Chen, Y.-Z., Yang, H., Zhang, Z.-K., and Qin, M.-Z. (2006a). Review of Approaches for Deriving Sediment Quality Guidelines. Adv. Earth Sci. 21, 53-61. (in Chinese).

Conder, J. M., Fuchsman, P. C., Grover, M. M., Magar, V. S., and Henning, M. H. (2015). Critical Review of Mercury Sediment Quality Values for the protection of Benthic Invertebrates. Environ. Toxicol. Chem. 34, 6-21. doi:10.1002/etc.2769

Du, M., Wei, D., Tan, Z., Lin, A., and Du, Y. (2015). Predicted No-Effect Concentrations for Mercury Species and Ecological Risk Assessment for Mercury Pollution in Aquatic Environment. J. Environ. Sci. 28, 74-80. doi:10.1016/j.jes.2014.06.042

ECB (2013). Directive 2013/39/eu of the European Parliament and of the council Amending Directives 2000/60/EC and 2008/105/EC as Regards Priority Substances in the Field of Water Policy.

Gaudet, C., Lingard, S., CuretonKeenleyside, P. K., Keenleyside, K., Smith, S., and Raju, G. (1995). Canadian Environmental Quality Guidelines for Mercury. Water Air Soil Pollut. 80, 1149-1159. doi:10.1007/bf01189777

Grandjean, P. (2007). Methylmercury Toxicity and Functional Programming is. Reprod. Toxicol. 23, 414-420. doi:10.1016/j.reprotox.2007.03.002

Guo, X.-Y., Gao, M., Zhang, J., Zhang, H.-T., Zhu, J.-G., and Deng, J.-C. (2019). Characteristics of Spatial Distribution and Biological Toxicity for Heavy Metals in Sediments of the Yangcheng Lake. China Environ. Sci. 39, 802 811, 2019 (in Chinese).

Hu, L.-F., Wang, Y.-H., Wang, Q.-Y., Lu, G.-H., Xie, Z.-X., and Zhang, Z.-H. (2014). Distribution and Ecological Risk Assessment of Mercury in Water, Sediments and Typical Aquatic Organisms from Northern Taihu Lake. J. Agro Environ. Sci. 33, 1183-1188. (in Chinese).

Huo, S.-L., Xi, B.-D., Yu, X.-J., Su, J., Zan, F.-Y., and Zhao, G.-C. (2013). Application of Equilibrium Partitioning Approach to Derive Sediment Quality Criteria for Heavy Metals in a Shallow Eutrophic lake, Lake Chaohu, China. Environ. Earth. Sci. 69, 2275-2285. doi:10.1007/s12665-0122056-6

\section{AUTHOR CONTRIBUTIONS}

FS: conceptualization, methodology, and software. HS: data curation and writing-original draft preparation. YT: investigation. YW: supervision. JY: software and validation. DS: writing-reviewing and editing.

\section{FUNDING}

This work was supported by the National Natural Science Foundation of China (Grant no. 41907306) and National Water Pollution Control and Management Technology Major Projects of China (Grant no. 2018ZX07208-001).

Huo, W.-Y., and Chen, J.-S. (1997). Water-particulate Distribution Coefficient of Heavy Metal and Application in Sediment Quality Criteria in China River. [J]. Environ. Sci. 18, 10-13. (in Chinese).

Jia, Y., Fang, M., Wu, Y.-J., Liu, H., Miao, Y., Wang, X.-T., et al. (2013). Pollution Characteristics and Potential Ecological Risk of Heavy Metals in River Sediments of Shanghai. China Environ. Sci. 33, 147-153. (in Chinese).

Jiang, B.-F., Sang, L.-X., Sun, W.-L., Hao, W., Li, L., and Deng, B.-S. (2013). Derivation and Application of Sediment Quality Criteria of $\mathrm{Cd}$ and $\mathrm{Hg}$ for the Xiangjiang River. Environ. Sci. 34, 98-107. doi:10.1016/s1872-2067(12)60600-7 in Chinese).

Jiang, L., Gong, X.-F., Yuan, S.-F., and Zhang, S.-K. (2020). Study on the Sediment Quality Criteria and Ecological Risk Assessment for Heavy Metals in Poyang Lake. Environ. Poll. Control. 42, 94-100. (in Chinese).

Kong, M., Peng, F.-Q., Zhang, Y.-M., Yin, H.-B., Liu, Z., and Chao, J.-Y. (2015). Occurrence Characteristic and Potential Risk Assessment of Heavy Metals in Surface Sediments of Circum-Chaohu Basin. China Environ. Sci. 35, 1863-1871. (in Chinese).

Li, H.-W., Zhang, Y.-F., Yang, J.-X., and Zhu, L.-Y. (2020). Ecological Risk Assessment and Verification of the Typical Heavy Metals for Sediment of Haihe River basin. Asian J. Ecotox. 15, 149-159, 2020 (in Chinese).

Li, L., Ping, X.-Y., Wang, Y.-L., Jiang, M., Tang, F.-H., and Shen, X.-Q. (2012). Spatial and Temporal Distribution and Pollution Analysis of the Heavy Metals in Surface Sediments of the Changjiang Estuary and its Adjacent Areas. China Environ. Sci. 32, 2245-2252. (in Chinese).

Lin, C.-Y., Zhou, Y.-X., Hu, L.-J., Guo, W., He, M. C., Yan, B.-X., et al. (2007). Ecological Risk Assessment of Mercury Pollution in the Sediment of Songhua River. Acta Scien. Circum. 27, 466-473. (in Chinese).

Liu, C., Shao, S.-G., Fan, C.-X., Zhou, Q.-L., and Shang, J.-G. (2014). Pollution Status and Risk Assessment of Heavy Metal in the Sediment of the Severe Polluted confluence Area of Lake Chaohu. China Enviro. Sci. 34, 1031-1037. (in Chinese).

Liu, S.-M., Yao, Q.-Z., Liu, Y.-L., Shan, K., Zhang, X.-X., Chen, H.-T., et al. (2012). Distribution and Influence Factors of Heavy Metals in Surface Sediments of the Yellow River Estuary Wetland. China Environ. Sci. 32, 1625-1631. (in Chinese).

Liu, W.-X., Luan, Z.-K., and Tang, H.-X. (1999). Sediment Quality Criteria for Heavy Metal Pollution in the Lean River II. Equilibrium Partitioning Approach. Acta Scien. Circum. 19, 230-235. (in Chinese).

MacDonald, D. D., Ingersoll, C. G., and Berger, T. A. (2000). Development and Evaluation of Consensus-Based Sediment Quality Guidelines for Freshwater Ecosystems. Arch. Environ. Contam. Toxicol. 39, 20-31. doi:10.1007/ s002440010075

MacDonald, D. D., Ingersoll, C. G., Smorong, D. E., Lindskoog, R. A., Sloane, G., and Biernacki, T. (2003). Development and Evaluation of Numerical Sediment Quality Assessment Guidelines for Florida Inland Waters. Technical Report. Tallahassee: Florida Department of Environmental Protection.

McElroy, A. E., Barron, M. G., Beckvar, N., Driscoll, S. B. K., Meador, J. P., Parkerton, T. F., et al. (2011). A Review of the Tissue Residue Approach for Organic and Organometallic Compounds in Aquatic Organisms. Integr. Environ. Assess. Manag. 7, 50-74. doi:10.1002/ieam.132 
Niu, Z., Cao, Y., Zhao, W., and Li, R. (2019). Distribution and Assessment of Mercury (Hg) in Surface Sediments of Futian Mangrove forest, China. Environ. Geochem. Health 41, 125-134. doi:10.1007/s10653-018-0151-7

Qiao, M.-M., Ji, H.-B., Zhu, X.-F., and Chen, Y. (2013). Fraction Distribution and Risk Assessment of Heavy Metals in Sediments of Inflow Rivers of Miyun Reservoir. Acta Scien. Circum. 33, 3324-3333. (in Chinese).

Sappington, K. G., Bridges, T. S., Bradbury, S. P., Erickson, R. J., Hendriks, A. J., Lanno, R. P., et al. (2011). Application of the Tissue Residue Approach in Ecological Risk Assessment. Integr. Environ. Assess. Manag. 7, 116-140. doi:10.1002/ieam.116

Shang, L. Y., Sun, R. H., Wang, Z. M., Ji, Y. H., and Chen, L. D. (2012). Assessment of Heavy Metal Pollution in Surface Sediments of Rivers in Northern Area of Haihe River Basin, China. Huan Jing Ke Xue 33, 606-611. (in Chinese).

Simpson, S. L., Batley, G. E., Hamilton, I. L., and Spadaro, D. A. (2011). Guidelines for Copper in Sediments with Varying Properties. Chemosphere 85, 1487-1495. doi:10.1016/j.chemosphere.2011.08.044

Smith, S. L., MacDonald, D. D., Keenleyside, K. A., and Gaudet, C. (1996). “The Development and Implementation of Canadian Sediment Quality Guidelines [A]," in Development and Progress in Sediment Quality Assessment: Rationale, Challenges, Techniques and Strategies. Editors M. Munarwar and G. Dave (Netherlands: SPB Academic Publishing), 233-249.

Su, H.-L., Feng, C.-L., Chang, H., Mu, Y.-S., and Wu, F.-C. (2015). Tissue Residue Guidelines of DDTs for the protection of Aquatic Mammalian Species in China. Asian J. Ecotox. 10, 23-30. (in Chinese).

Su, H.-L., Guo, F., Wei, Y., Shi, D., and Sun, F.-H. (2020). Study on Methylmercury Water Quality Standards for Aquatic Life protection in China. J. Environ. Eng. Tec. 10, 512-516. (in Chinese).

USEPA (2016). Aquatic Life Ambient Water Quality Criterion for SeleniumfreshwaterOffice of Water, Office of Science and Technology. Washington D.C, 2016 EPA 822-R-16-006.

USEPA (2005). Procedures for the Derivation of Equilibrium Partitioning Sediment Benchmarks (ESBs) for the protection of Benthic Organisms: Metal Mixtures (Cadmium, Copper, Lead, Nickel, Silver, and Zinc). Washington DC EPA/600/ $\mathrm{R}-02 / 011$.

Van Der Kooij, L. A., Van De Meent, D., Van Leeuwen, C. J., and Bruggeman, W. A. (1991). Deriving Quality Criteria for Water and Sediment from the Results of Aquatic Toxicity Tests and Product Standards: Application of the Equilibrium Partitioning Method. Water Res. 25, 697-705. doi:10.1016/0043-1354(91)90045-r

Wang, Q., Liu, R., MenXu, C. F., Xu, F., Guo, L., and Shen, Z. (2017). Spatialtemporal Distribution and Risk Assessment of Mercury in Different Fractions in Surface Sediments from the Yangtze River Estuary. Mar. Pollut. Bull. 124, 488-495. doi:10.1016/j.marpolbul.2017.07.034

Webster, J., and Ridgway, I. (1994). The Application of the Equilibrium Partitioning Pproach for Establishing Sediment Quality Criteria at Two UK
Sea Disposal and Outfall Sites. Mar. Pollut. Bull. 28, 653-661. doi:10.1016/0025326x(94)90300-x

Wen, Q., Zhao, Y.-M., Cao, W., Yang, C.-C., Zhang, L., Zhang, G.-Y., et al. (2020). Distribution Characteristics, Sources and Potential Ecological Risks of Heavy Metal Pollution in the Middle Reaches of Chaobai River. Res. Environ. Sci. 33, 599-607. (in Chinese).

Wu, F., Meng, W., Zhao, X., Li, H., Zhang, R., Cao, Y., et al. (2010). China Embarking on Development of its Own National Water Quality Criteria System. Environ. Sci. Technol. 44, 7992-7993. doi:10.1021/es1029365

Xu, Z.-X., and Zhang, M. (2013). Spatial Distribution and Pollution Assessment of as and $\mathrm{Hg}$ in Sediments from Taihu Lake Watershed. Resour. Environ. Yangtze Basin. 22, 626-632. (in Chinese).

Yin, H.-B., Gao, Y.-N., and Fan, C.-X. (2011). Distribution, Sources and Ecological Risk Assessment of Heavy Metals in Surface Sediments from Lake Taihu, China. Environ. Res. Lett. 6, 044012. doi:10.1088/1748-9326/6/4/044012

Zhai, W.-Y., Ouyang, X.-J., Zhou, W., Yu, D., and Zheng, H.-Y. (2017). Spatial Distribution and Risk Assessment of Heavy Metals in the Nearshore Sediments in Main Stream of Yangtze River. Acta Scien. Circum. 37, 4195-4201. (in Chinese).

Zhang, R.-Q., Wu, F.-C., Li, H.-X., Feng, C.-L., and Guo, G.-H. (2012). Deriving Aquatic Water Quality Criteria for Inorganic Mercury in China by Species Sensitivity Distributions. Acta Scien. Circum. 32, 440-449. (in Chinese).

Zhu, L.-Y., Deng, B.-L., Liu, N.-N., Hu, F.-Y., and Wang, H. (2009b). Application of Equilibrium Partitioning Approach to Derive Sediment Quality Criteria for Heavy Metals. Res. Environ. Sci. 22, 762-767. (in Chinese).

Zhu, L.-Y., Liu, N. N., and Deng, B. L. (2009a). Sediment Quality Criteria for Organic Pollutants Based on Phase-Equilibrium Partitioning Approach: a Review. Ying Yong Sheng Tai Xue Bao 20, 2574-2580. (in Chinese).

Zhuang, W., and Gao, X. (2015). Distributions, Sources and Ecological Risk Assessment of Arsenic and Mercury in the Surface Sediments of the Southwestern Coastal Laizhou Bay, Bohai Sea. Mar. Pollut. Bull. 99, 320-327. doi:10.1016/j.marpolbul.2015.07.037

Conflict of Interest: The authors declare that the research was conducted in the absence of any commercial or financial relationships that could be construed as a potential conflict of interest.

Copyright $\odot 2021$ Su, Shi, Yang, Tao, Sun and Wei. This is an open-access article distributed under the terms of the Creative Commons Attribution License (CC BY). The use, distribution or reproduction in other forums is permitted, provided the original author(s) and the copyright owner(s) are credited and that the original publication in this journal is cited, in accordance with accepted academic practice. No use, distribution or reproduction is permitted which does not comply with these terms. 